\title{
ПІДВИЩЕННЯ ЕФЕКТИВНОСТІ РОБОТИ СЛУЖБ МАТЕРІАЛЬНО-ТЕХНІЧНОГО ЗАБЕЗПЕЧЕННЯ ПІДПРИЕМСТВ
}

\author{
Представив д-р техн. наук, професор Л.А. Тимофеєва
}

\begin{abstract}
Постановка проблеми у загальному вигляді, іiі зв'язок 3 важливими науковими та практичними завданнями. В останні 15-20 років в економіці розвинених країн відбулися істотні зміни. Ці зміни стосуються і України. У господарську практику підприємств і фірм стали впроваджувати нові методи й технології доставки товарів, що базуються на концепції інтеграції транспорту й матеріально-технічного забезпечення та впровадження новітньої техніки в галузі інформатики й комунікацій. Можна стверджувати, що 3 рубежу $70-80$ років $\mathrm{XX}$ століття почалося органічне зрощення транспорту 3 виробництвом, що його обслуговує, і перетворення його в ланку єдиної системи «виробництво-транспортрозподіл». Новий підхід до транспорту як ключової частини логістичного ланцюга призводить до необхідності розгляду його в різних аспектах.
\end{abstract}

Аналіз останніх досліджень i публікацій. У роботах [1-7] розглянуто різноманітні шляхи підвищення ефективності функціонування складського господарства. Наприклад, у роботі [4] проблему оптимізації функції управління запасами запропоновано вирішувати за допомогою програмних продуктів («SimpleSystem»). Пропонуються також методи удосконалення системи транспортування та складування. Але потребує уваги питання зменшення витрат на створення i утриманням запасів. Матеріальні запаси це продукція виробничо-технічного призначення, що знаходиться на різних стадіях виробництва та обігу, вироби широкого вжитку й інші товари, що очікують вступу в процес виробничого або особистого споживання. На рівні фірм запаси належать до числа об'єктів, що вимагають більших капіталовкладень, i тому являють собою один $з$ факторів, що визначає політику підприємства й впливає на рівні логістичного обслуговування в цілому. Однак багато фірм не приділяють йому належної уваги й постійно недооцінюють свої майбутні потреби наявних запасів. У результаті цього фірми звичайно зіштовхуються 3 тим, що їм доводитися вкладати в запаси більший капітал, ніж передбачалося.

Мета дослідження: розроблення можливих шляхів зменшення логістичних витрат підприємства за рахунок впровадження новітніх досягнень у сфері управління матеріальними запасами.

Основна частина. Створення запасів завжди сполучено 3 витратами. До основних видів витрат, пов'язаних зі створенням i втримуванням запасів, відносять:

- заморожені фінансові кошти;

- витрати на утримання спеціально обладнаних приміщень;

- оплату праці обслуговуючого персоналу; 
- втрати від псування, розкрадання.

До основних видів втрат, пов'язаних 3 відсутністю запасів, відносять:

- втрати від простою виробництва;

- втрати від відсутності товару на складі в момент пред'явлення попиту;

- втрати від закупівлі дрібних партій товару по більш високих цінах і т. ін.

Наявність товарно-матеріальних запасів завжди вважалося фактором, що забезпечує безпеку системи матеріальнотехнічного постачання, iï гнучке функціонування і є своєрідною страховкою. Найбільш доцільною для підприємств залізничного транспорту виявляється система управління запасами з фіксованим інтервалом часу між замовленнями за умови, що буде вестися суворий контроль за наявністю запасних частин на складі.

Оптимальний розмір замовлення безпосередньо не використовується в роботі системи 3 фіксованим інтервалом часу між замовленнями, але дає можливість запропонувати ефективний інтервал часу між замовленнями, величина якого необхідна як вихідний параметр. Відношення величини потреби до оптимального розміру замовлення дорівнює кількості замовлень у заданий період. Кількість робочих днів у заданому періоді, віднесене до кількості замовлень, дорівнює інтервалу між замовленнями, що відповідає оптимальному режиму роботи системи. днів,

Інтервал часу між замовленнями,

$$
\text { ИВМЗ = ЧРД • ОРЗ / П, }
$$

де ЧРД - кількість робочих днів у періоді, доба;

ОРЗ - оптимальний розмір замовлення, шт.;

П- потреба, шт.

Максимально бажаний запас, грн,

$$
\text { МЖЗ = ГЗ +ИВМЗ • ОДП, }
$$

де ГЗ - гарантійний запас, грн;

ИВМЗ - інтервал часу між замовленнями, доб;

ОДП - очікуване денне споживання, грн/ доб.

Графічне моделювання роботи системи управління запасами з фіксованим інтервалом часу між замовленнями за наявності збоїв наведено на рис. 1.

Прогнозування, планування й нормування матеріальних запасів вимагає вирішення завдання оптимізації номенклатури запасних частин, що входять до складу матеріальних запасів підприємства. Результати досліджень експлуатаційної надійності машин i механізмів показують, що $\epsilon$ обмежена кількість деталей, які частіше за інших виходять із ладу й тим самим визначають трудові й матеріальні витрати на підтримку техніки у працездатному стані.

$$
\text { Для зручності розрахунків }
$$
використовуємо відносні величини розглянутих вартісних показників $q_{i}$ (у відсотках)

$$
q_{i}=\frac{C_{i}}{\sum_{i=1}^{N} C_{i}} \cdot 100 \%
$$

де $C_{i}$ - потреба в $\mathrm{i}-$ й запчастині на розрахунковий період, грн;

$\sum_{i=1}^{N} C_{i}$ - потреба на всі запчастини за розрахунковий період, грн.

Величини $q_{i} \quad$ підсумовуються наростаючим підсумком $q \sum i=\sum q i \quad$ i залежно від наступного способу визначення номенклатурних груп надаються у вигляді графіка (графічний метод). 


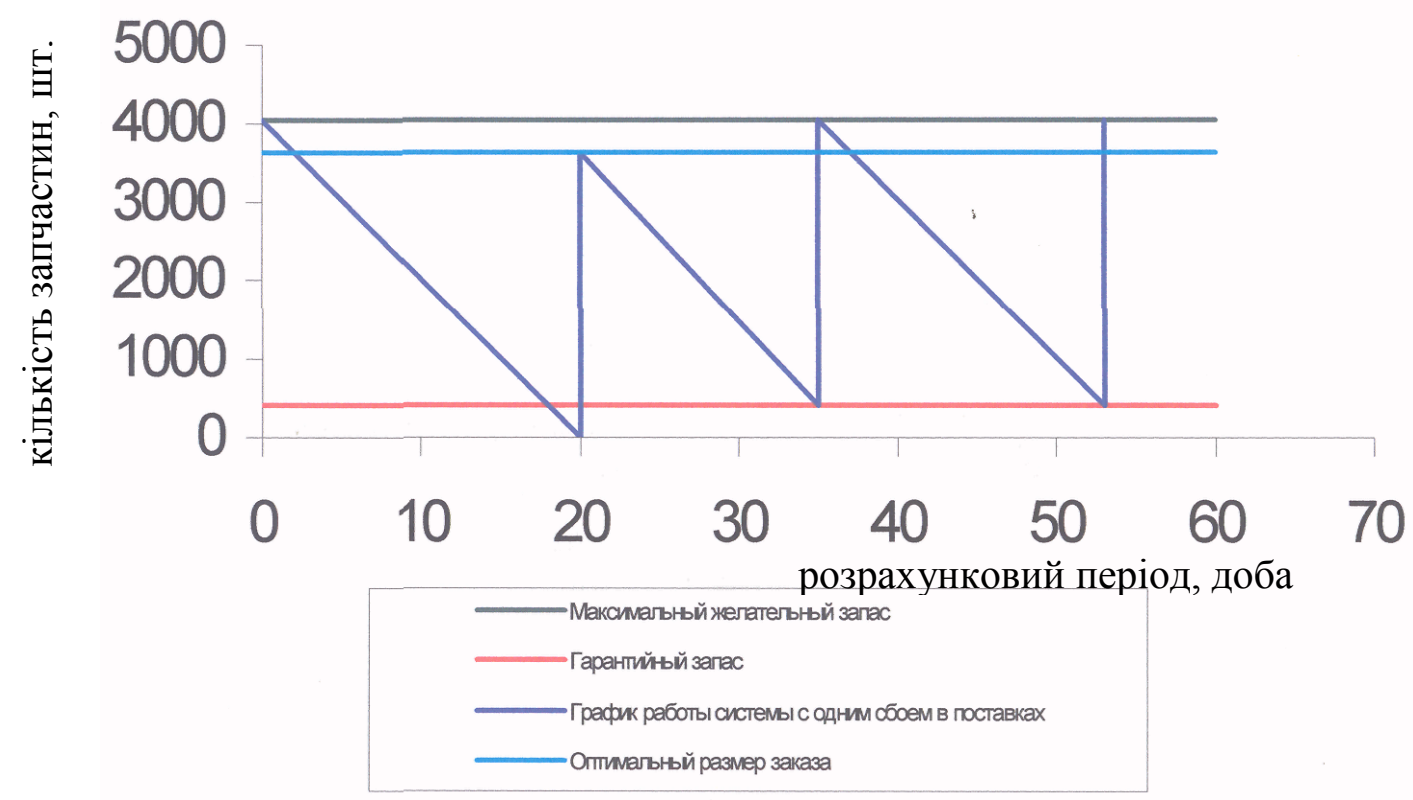

Рис. 1. Графічна модель роботи системи управління запасами з фіксованим інтервалом часу між замовленнями за наявності однієї затримки в поставках

На рис. 2, на осі ординат наносяться значення $q \sum i$, на осі абсцис - індекси $1,2, . ., \mathrm{i}$, що відповідають привласненим номерам позицій номенклатури запасних частин. Точки на графіку з'єднуються плавною кривою ABD, що у загальному випадку $\epsilon$ опуклою. Потім проводиться дотична LM до кумулятивної кривої $\mathrm{AD}$, паралельно прямій $\mathrm{AD}$. Пряма $\mathrm{AD}$ відповідає рівномірному розподілу витрат по всій номенклатурі, тобто характеризує частку «певної» деталі в загальному показнику. Абсциса точки дотику В, округлена до найближчого цілого значення, відокремлює від всієї номенклатури деталей першу групу (група А), у яку входять деталі з показником $q_{1}, q_{2}, q_{3}, q_{4}$, $q_{5}$, Відповідно ордината точки вказує частку групи деталей $\mathrm{y}$ загальному показнику $q \sum i$. Продовжимо розподіл на групи номенклатури деталей, що залишилася, скориставшись описаним вище прийомом. З'єднаємо крайні точки В і D i проведемо дотичну NR до кривої BCD, паралельну проведеній прямій $\mathrm{BD}$. Абсциса точки дотику C ділить номенклатуру, що залишилася, деталей також на дві групи: група В і група С. Таким чином, у групу В попадають деталі з показником $q_{6}, q_{7}, q_{8}$, а в групу С попадають всі інші.

Висновки 3 дослідження i перспективи, подальший розвиток у даному напрямку. На обраному промисловому підприємстві щорічний економічний ефект від впровадження запропонованої системи управління запасами, а також від раціоналізації номенклатури складських запасів становитиме близько 200 тис. грн. Причому впровадження запропонованих заходів не потребує додаткового залучання технічних або фінансових ресурсів. 


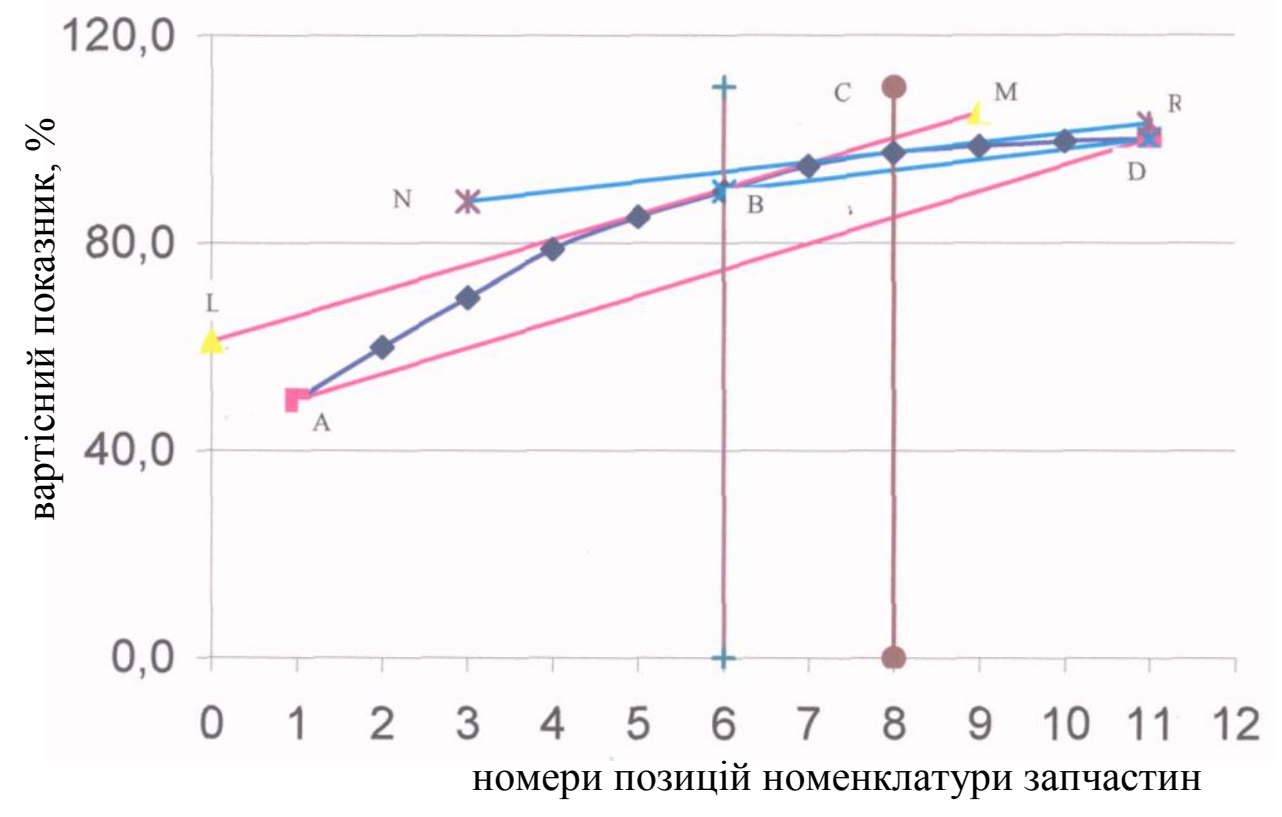

Рис. 2. Визначення номенклатурних груп методом АВС

\section{Список літератури}

1. Организация производства и управление предприятием [Текст]: учебник / О.Г. Туровец, М.И. Бухалков, В.Б. Родинов [и др.]; под ред. О.Г. Туровца. - М.: ИНФРА-М, 2003. $-420 \mathrm{c}$.

2. Гаджинский, А.М. Логистика [Текст]: учебник / А.М. Гаджинский. - М.: ИВЦ "Маркетинг", 1998. - 230 с.

3. Транспортная логистика [Текст]: учеб. для транспортных вузов /под общ. ред. Л.Б. Миротина. - М.: Издательство "Экзамен", 2002. - 295 с.

4. Ветров, А.С. Резервы совершенствования управления материальными потоками в складском хозяйстве машиностроительного предприятия [Текст]: дис. ... канд. экон. наук / А.С. Ветров. - М., 1999. - 175 с.

5. Каптерев, А.И. Совершенствование информационного обслуживания складского хозяйства [Текст] / А.И. Каптерев, В.И. Рыблов // Риск: ресурсы, информация, снабжение, конкуренция. - 2010. - № 4 - С. 8-12.

6. Гусев, В.Г. Пути повышения эффективности функционирования складского хозяйства [Текст] / В.Г. Гусев, Х.С. Колесникова, И.И. Игумнова // В мире научных открытий. - 2010. - № 4-16. - С. 141-142.

7. Лукайский, В.А. О развитии концепции управления запасами в цепях поставок [Текст] / В.А. Лукайский // Логистика. - 2007. - № 4 - С. 17-18.

Ключові слова: транспорт, логістичний ланцюг, товарно-матеріальні запаси, номенклатура деталей, матеріальні ресурси, системи матеріально-технічного забезпечення.

\section{Анотації}

Розроблено можливі шляхи зменшення логістичних витрат підприємства за рахунок впровадження новітніх досягнень у сфері управління матеріальними запасами. 
Запропоновано такі організаційні заходи: застосування теорії імовірності для визначення потреб у матеріальних ресурсах підприємства; застосування системи 3 фіксованим інтервалом часу між замовленнями; застосування сучасного методу виділення номенклатури запасних частин за групами важливості. Запропоновані організаційні методи є логічними, а їх впровадження економічно доцільним.

Разработаны возможные пути уменьшения логистических затрат предприятия за счет внедрения новых достижений в сфере управления материальными запасами. Предложены следующие организационные методы: использование теории вероятности для определения потребностей в материальных ресурсах предприятия; использование системы с фиксированным интервалом времени между заказами; использование современного метода выделения номенклатуры запасных частей по группам важности. Предложенные организационные методы логичны, а их внедрение экономически целесообразно.

Possible ways of an enterprise logistic expenditure reduction by means of materials inventory control new achievements introduction have been developed. The following organizational methods have been proposed: the employment of probability theory for the estimation of enterprise material resources necessities; the employment of the system with the fixed time domain between the orders; the employment of the modern method of nomenclature selection of spare parts on the groups of importance. The introduced organizational methods are consequent and their introduction is economically expedient. 